\title{
The Impact of Desegregation on College Choices of Elite Black Athletes
}

\author{
Dr. George R. La Noue ${ }^{1} \&$ Mark Bennett ${ }^{2}$ \\ ${ }^{1}$ Research Professor of Political Science, Research Professor of Public Policy \\ ${ }^{2}$ Master's in Public Policy, University of Maryland Baltimore County \\ Correspondence: Dr. George R. La Noue, Research Professor of Political Science, Research Professor of Public \\ Policy. Tel: 410-455-2180. E-mail: glanoue@umbc.edu
}

Received: July 29, 2014

doi:10.5430/ijhe.v3n3p142
Accepted: August 12, 2014

Online Published: August 21, 2014

URL: http://dx.doi.org/10.5430/ijhe.v3n3p142

\begin{abstract}
Even a casual observer of American college athletics can see the emergence of star black athletes in conferences that once were racially segregated. By analyzing the college origins of National Football League and National Basketball Association draft choices between 1947 and 2011, this research measures the impact of higher education desegregation on the choices of elite African-American athletes in moving from historically black institutions (HBIs) to traditionally white institutions (TWIs). Using draft data and narrative descriptions, this paper documents when, why, and how this shift occurred.

The desegregation of American education sometimes had the perverse effect of increasing opportunities for individual African-Americans, while subordinating the role or even extinguishing the black institutions serving that population in the Jim Crow era. In the desegregated era, there are some benefits to individual black athletes whose high professional draft status may make them young millionaires and to the states which have replaced a rigid odious racial color consciousness with fans cheering for university team colors worn by both their black and white athletes. But there is a price paid by the athletic programs of HBIs who are now confined to lower level conferences away from the most publicized contests. Some data reflected in the paper suggests that HBIs are losing in the competition to recruit elite black students in non-athletic fields as well.
\end{abstract}

Keywords: Desegregation, Black athletes, Professional sports, Historically black colleges and universities (HBCUs)

\section{Introduction}

The underlying theory of this research is that the desegregation of American life sometimes had a perverse effect. It increased opportunities for individual African-Americans, while subordinating the role of or even extinguishing the black institutions serving that population in the Jim Crow era. After the passage of the Civil Rights Act, in many urban areas black entertainment districts fell on hard times and their restaurants, hotels, and theaters withered away. In towns or cities with smaller black populations, it was often the black school that was closed to achieve integration. In higher education, the perverse effect can be seen in the rise and fall of black athletic teams.

Higher education presented a complex desegregation challenge. After the Civil War, more than one hundred public and private higher educational institutions were founded to serve African-American students in southern and some border states (U.S. Department of Education, 2007). Today they are commonly called historically black colleges and universities (HBCUs or HBIs). How should governments respond to HBCUs after the desegregation of traditionally white institutions (TWIs)? Should public policy seek to end all institutional racial identifiability as was the goal in K-12 education, or should HBCUs with their racial traditions largely intact be enhanced to compete with TWIs on an equal basis?

This question has been the focus of numerous court decisions, Office of Civil Rights -mandated desegregation plans, and state commissions. After these considerations, HBCUs generally have won increased financial support and program protections from TWI competition; even as the percentage of college-enrolled African-Americans attending HBCUs has steadily declined from 18.4 percent in 1976 to 10.6 percent in 2007 (National Center for Education Statistics, 2011). As black students and faculty have been vigorously recruited by better funded and more prestigious TWIs that once excluded or ignored them, what has been the effect on HBCUs? Has public policy had the effect of propping up HBCUs that may no longer be the best options for most African-Americans?

While these questions form an important context for this research, answering them would require several volumes 
and would extend far beyond the data examined here. This paper focuses on a much narrower topic which can be measured empirically. What has been the effect of desegregation on the college choices of elite black athletes? The answer to that question, however, may provide some insight into some of the larger desegregation policy issues.

\section{Literature Review and Research Methodology}

There is an extensive literature related to higher education desegregation. Henry Allen Bullock's (1967) A History of Negro Education in the South provides a valuable overview of the social and political context of the development of HBCUs, but it was published before much higher education desegregation had occurred (Bullock, 1967). In a more recent treatment of HCBU history, The White Architects of Black Education, William Watkins (2001) ends his description in 1954. Alvis Adair (1984) more directly confronts the post-Brown period in his book, Desegregation: The Illusion of Black Progress. He suggests that, while there were substantial legal gains in the desegregation era for many African-Americans, there were also costs in the declining employment of black teachers and in the discontinuation of institutions serving black students. Thus, he welcomed policies favoring the continuation of black schools. In his article, "A Backward Glance Forward: Past, Present and Future Perspectives on Historically Black Colleges and Universities," Allen (2002) ties the history of HCBUs to their future in the desegregated era. He concludes that their special role and handicaps dating back to their founding led many HBCUs to develop into less complete collegiate institutions which created competitive problems for them in the new era. A volume containing a series of essays published by the National Association for Equal Opportunity in Higher Education (an organization of HBCUs) examines various advantages and disadvantages of these institutions (Meyers, 1989).

The United States Supreme Court rendered its only higher education desegregation decision (United States v. Fordice, 1992) almost four decades after it desegregated K-12 education (Brown v. Board of Education, 1954). Examining Mississippi higher education, the Court held that states had the obligation to dismantle dual higher education systems. Options might include merging or closing some institutions and creating common admission standards, even though that might threaten HBCUs. Justice Thomas, the only African-American on the Court, wrote a concurring opinion:

I think it undisputable that these institutions have succeeded in part because of their distinctive histories and traditions; for many, historically black colleges have become 'a symbol of the highest attainments of black culture'....It would be ironic, to say the least, if the institutions that sustained blacks during segregation were themselves destroyed in an effort to combat its vestiges (Leiter \& Leiter, 2002, p. 163)

At many HBCUs an important part of that racial culture has been athletic competitions accompanied by distinctive musical performances and other social activities. Those games and celebrations certainly continue. A Grambling versus Southern game, often held in the Louisiana Superdome, is a memorable spectacle where the bands are as competitive as the football teams (Davis, 2003). In the $21^{\text {st }}$ Century, however, those contests, as notable as they may be, are often overshadowed in public attention by many regular season Southeastern Conference games which averaged 76,719 spectators in 2011 (Jonson, 2011). The difference in the desegregated era is that many of the athletes playing for Southeastern Conference opponents will be African-American, which was not possible in the Jim Crow period.

There has been some journalistic speculation about the migration of talented black athletes from HBCUs to TWIs (Jones, 2007), but no scholarly attempt has been made to measure that trend. It is obvious to the most casual observer that black athletes playing for teams in the formerly segregated Atlantic Coast, Southeastern and Big 12 (nee Southwestern) conferences are playing starring roles, but what has that migration meant for HBCUs?

Examination of these all-conference football and basketball teams shows the emergence of black athletes in leagues that once were segregated. Candidates for the Naismith (basketball) and Heisman (football) trophies for the best athlete in those sports display the prominence of black athletes on the national stage. In neither of these competitions, however, are HBCU athletes involved, since they do not play in conferences or in the games that create national publicity.

Away from the TV cameras, however, there is another form of athletic competition that may be a more objective evaluation of the trends in the enrollment of elite black athletes. Every year, the National Basketball Association (NBA) and the National Football League (NFL) draft hundreds of college athletes after evaluating their potential as future professionals. These draft outcomes are determined, not by highlight reels or publicity campaigns, but by stopwatches, sharp-eyed scouting reports, and rigorous try-out camps. Analyzing these draft choices from 1947-2011 thus provides an empirical basis for examining how professionals over the years have evaluated the athletic talent coming out of both HBCUs and TWIs. Adjustments have been made to exclude draftees that came from international sources or high schools and to reflect changes in the number of professional teams. 


\section{Desegregating Higher Education}

Education for black Americans remained legally segregated in southern and border states until the Supreme Court's 1954 Brown v. Board of Education decision. While the process of desegregating K-12 education was difficult legally and politically, for the most part there was agreement among federal authorities that public policies perpetuating the racial identifiablity of schools were wrong. Though change might be wrenching for both whites and blacks, in the words of the Brown Court, "Separate educational facilities are inherently unequal" (Brown, 1954, p.495). In the South, the Fifth Circuit, frustrated by excessively slow or evasive behaviors, required that all previously legally segregated districts to take positive action to achieve unitary status declaring: "The only school desegregation plan that meets constitutional standards is one that works" (U.S. v. Jefferson County Board of Education, 1966, p. 2-3).

Desegregating higher education was more complicated logistically and morally. Students freely select the in-state or out-of-state college or university they will attend, and, unlike K-12, there are often many choices. The range in curricula, missions, facilities, and budgets is much greater in higher education than in K-12. Faculty and administrators cannot easily be reassigned to other institutions. Most significantly, higher education institutions often develop strong alumni and political ties which shield and support them. Not surprisingly, many of the African-American politicians in formerly segregated states were graduates of HBCUs.

In 1969, the NAACP Legal Defense Fund (LDF) sued to force the Department of Health, Education and Welfare to speed up higher education desegregation enforcement in a case called Adams v. Richardson (1973). The suit urged federal officials to create a prompt end to racial identifiablity, the LDF's traditional strategy for creating equal opportunity. The National Association for Equal Opportunity in Higher Education, a membership group of HBCUs, however, saw desegregation as a threat to their institutions.

Raymond Dawson, a University of North Carolina educator, explained the HBCU belief that as:

...the victim of discrimination and segregation that they should not be singled out as a part of the remedy. ...their position was that, you know that they were in full compliance with the law and that insofar as the make up for their student bodies were concerned, they had always been open to all. The fact that they were, were of a clearly racial identifiability was because of the law of the oppressors. And so the dire consequences ought to fall on the oppressors and that what should be done as remedy was to build up and strengthen the black institutions. (Link, 1991, p. 3)

The split in opinion about the best course in higher education desegregation has never been fully reconciled. Most HBCU advocates have insisted that the proper civil rights strategy is to enhance the physical facilities, operating budgets, and program allocations of their institutions. Those steps would certainly assist the black students attending HBCUs and theoretically attract more white students as well. Federal authorities largely accepted that position. Skeptics, however, point out that HBCUs enroll a declining percentage of black students and non-black students have generally not chosen those campuses regardless of enhancements. HBCUs respond that their race-based attendance profiles because those campuses have not yet achieved full equality, but others believe that it is partly a problem of their own making. The federal court in the desegregation case Knight v. Alabama (2002) found "The desire of an HBI to maintain racial identifiability extracts an intangible, but very real cost in the desegregation process. It makes it very difficult to recruit white students to the college" (p.314). In defending against a 2011 lawsuit to further enhance HBCUs, the state of Maryland pointed out that, while its HBCUs complained about their difficulty in attracting white students, they "embraced their history as historically black schools and highlight in their mission statements and their websites and other marketing tools their continuing commitment to operate as HBIs" (Coalition for Educational Equity and Excellence in Maryland Higher Education v. Maryland Higher Education Commission, 2013, p.21).

While HBCUs have won important gains in equality of funding and capital facilities in many states, those new revenues have not generally affected their athletic budgets. States may conclude that libraries and science labs need to be equal at HCBUs and comparably sized TWIs, but they are less inclined to see that need for equality in stadiums and arenas, many of which are financed with considerable private support and TV revenues. Furthermore, the major athletic conferences are largely composed of a few wealthy private universities and flagship public institutions, none of which are HBCUs. While individual athletic contests between HBCUs and TWIs are not uncommon, the former have remained largely in all black conferences mostly established before the civil rights era: Central Intercollegiate Athletic Association (1912); Mid-Eastern Athletic Conference (1970); the Southern Intercollegiate Athletic Conference (1913); and the Southwestern Athletic Conference (1920), (Starks, 2006).

\section{College Athletics and Desegregation}

Before desegregation, African-American athletes in southern and border states desiring to play college level sports 
regionally could only choose among HBCUs. After the gradual integration of college sports, African-American athletes were often vigorously recruited nationally and the best of them had a wide variety of choices about which university they would attend (Marshall, 2011).

Prior to desegregation, HBCUs often enrolled athletes of exceptional talent. One such example, Earl Lloyd, who was drafted from West Virginia State in 1950 by the Washington Capitals, was the first African American to play in an NBA game. He later was the star forward for the 1954-55 Syracuse Nationals (who moved to Philadelphia in 1963 to become the 76ers) (Ramsey, 2005). Sam Jones, drafted from North Carolina Central University in 1957 in the First Round, went on to win ten national championships with the Boston Celtics, leading his team in scoring for three of those ten years (Sports Reference, 2011). Willis Reed, drafted in the1964 NBA second round from Grambling State, later won a national championship with the New York Knicks, and was named one of the fifty greatest NBA players of all time. Earl "The Pearl" Monroe from Winston-Salem State was drafted in 1967 by the Baltimore Bullets in the first round and promptly became NBA rookie of the year. He finished his career by being elected to the Naismith Memorial Hall of Fame and joined Reed on the fifty greatest NBA players list (National Basketball Association, 2011).

Players like these, often better than their "white counterparts," were arriving at HBCUs in considerable numbers because they were the only option to play in college (Nealy, 2008). As HBCU North Carolina Central Athletic Director Bill Hayes put it, before integration there was "easy access to fantastic athletes" (Jones, 2007, p.1).

The outcome of HBCU access and the intransigence of white universities were depicted in the four-hour ESPN Documentary, "Black Magic," which chronicled the prominent African-American players and coaches before integration. The documentary highlighted the "secret game," a 1944 showdown between a team from all white Duke University and all black North Carolina College for Negroes (NCC) in legally segregated Durham. During the war Duke was the site of the Army and Navy training programs and many former college athletes played for university club teams. The best team was connected to the medical school which featured former stars from Richmond, Montana, Duke and several small white colleges (Ellsworth, 1996).

The game was scheduled for Sunday March 12, 1944, in the morning hours while Durham citizens attended church. The gym doors were locked with only a referee, players and coaches inside. According to the North Carolina History Project, "No one uncovered the secret game: neither the Durham police nor the premier Durham newspapers (like the Durham Morning Herald and the Durham Sun). Even though a reporter from the Carolina Times (an African American weekly) knew about the game, he agreed not to publish the story to protect the players and coaches involved" (Dunne, 1996, p.1). In the end, the score, 88-44 NCC over the Duke team, suggested just how talented black players were when they could leave their segregated enclaves (Nealy, 2008).

The documentary also featured HBCU coaches. NCC coach John McLendon's victory was a precursor to what would be an exceptional career. After he moved to HBCU Tennessee A \& M, (now Tennessee State University) Coach McLendon won three National Association of Intercollegiate Athletics championships, (1957, '58, '59) (History \& Legends, 2011) which led the National Collegiate Athletic Association (NCAA) finally to admit black colleges.

Athletic conferences and competitions in southern and border states were still segregated, even after the passage of the Civil Rights Act of 1964 (Fitzpatrick, 2003). One remarkable event in 1966 changed college basketball forever. Inside the University of Maryland's Cole Field House in College Park, the Texas Western Miners faced defending national champions University of Kentucky Wildcats for the NCAA title (Wolff, 2007). When both teams took the floor, there was something remarkably different about them. Don Haskin's Miners starting squad consisted of five African-American players, though the school was not an HBCU, while Adolph Rupp's Wildcats were all white. Unlike the Durham secret game, this championship was played for the entire nation to see (Wolff, 2007). In the end, the Miners won 72-65. "What a piece of history," remarked Nolan Richardson, national champion and former player for Haskins at Texas Western, "If basketball ever took a turn, that was it" (Fitzpatrick, 2003, p.1).

When college basketball fans saw this game and its unmistakable lesson, coaches enthusiastically began to integrate their programs to incorporate the exceptionally talented black athletes. According to ESPN Classic, Don Haskin's win "accelerated the advancement of black athletes in the South...All-white leagues like the Atlantic Coast Conference, Southwestern Conference and Southeastern Conference became integrated within the next two years" (Fitzpatrick, 2003, p.1). Overall, between 1966 and 1985, the average number of African Americans on college sports teams jumped from 2.9 to 5.7. The southern conferences were finally catching on that integration was not just a moral issue that divided their constituencies. To compete "Southern basketball teams would have to change or become increasingly noncompetitive nationally" (Fitzpatrick, 2003, p. 1). Now black athletes were not just given the option to attend historically black institutions, they were being actively recruited by major white state universities, 
which meant that recruiting elite young black athletes for HBCUs was about to become very difficult (Jones, 2007).

The change in enrollment patterns of elite black athletes after desegregation can be seen by analyzing draft choice decisions by the National Basketball Association (NBA) and the National Football League (NFL). These records can be used to pinpoint the colleges of origin of the most talented players. This research examines those trends between 1947-2010.

Table 1 compares the overall number of all college basketball players drafted into the NBA and comparing that number to those drafted from HBCUs. There are dramatic differences in the total number of players drafted, so the percentage of HBCU draftees is more significant than the raw number. When the NBA draft began teams would select players until prospects ran out, for example in 1960 there were 21 rounds. In 1989 the NBA dropped to only two rounds.

Currently, there are 105 HBCUs (U.S. Department of Education, 2011) and prior to desegregation, they produced professional athletes far out of proportion to their enrollments or facilities. Forty-seven HBCUs have had players drafted into the NBA. From 1947 (the year the NBA draft began) to 2011, 7,527 players were drafted from colleges and universities to play in the NBA. Of these, 176 came from HBCUs, or approximately $2.3 \%$ of all players drafted into the NBA from college. (Players drafted directly from high school or with international backgrounds are excluded from these calculations). The chronological trends in the participation of HBCU athletes are the more interesting statistics.

Table 1. HBCU athletes in the NBA Draft (1947-2011)

\begin{tabular}{cccc}
\hline Year & $\begin{array}{c}\text { Total college players } \\
\text { drafted into the NBA }\end{array}$ & $\begin{array}{c}\text { Players drafted from } \\
\text { HBCUs }\end{array}$ & $\begin{array}{c}\text { Percent of players from } \\
\text { HBCUs }\end{array}$ \\
\hline $\mathbf{1 9 4 7 - 1 9 5 9}$ & 1,235 & 12 & $0.97 \%$ \\
$\mathbf{1 9 6 0 - 1 9 6 9}$ & 1,311 & 45 & $3.43 \%$ \\
$\mathbf{1 9 7 0 - 1 9 7 9}$ & 1,951 & 64 & $3.28 \%$ \\
$\mathbf{1 9 8 0 - 1 9 8 9}$ & 1,730 & 29 & $1.67 \%$ \\
$\mathbf{1 9 9 0 - 1 9 9 9}$ & 518 & 19 & $3.67 \%$ \\
$\mathbf{2 0 0 0 - 2 0 1 1}$ & 532 & 7 & $0.94 \%$ \\
$\mathbf{1 9 4 7 - 2 0 1 1}$ & 7,277 & 176 & $2.42 \%$ \\
\hline
\end{tabular}

Source: BasketballReference.Com, NBADraftHistory.com.

As unbelievable as it now seems, the NBA did not accept black players until 1951, so none were selected when the draft began in 1947. In 1948, however, the all-black Harlem Globetrotters abandoned their clownish entertainment image long enough to play serious basketball and beat the NBA Champion Minneapolis Lakers, two games to one in exhibition games (Thornley, 1989). The league got the message.

Twelve players from HBCUs, who had rarely played against whites, were drafted into the NBA from 1947 to 1959 (NBA Draft History, 2011). In the decade of the Sixties, the number of HCBU draftees quadrupled as professional scouts looking for African-American players discovered black campuses as new sources of talent. In the Seventies, draftees from HBCUs reached their highest number (64), but as integration of college athletics in the south became more common, the HBCU numbers declined in each subsequent decade. In the Eighties, there were $29 \mathrm{HBCU}$ draftees, the Nineties 19 and after the turn of the century 7.

Overall, the data suggest that HBCUs steadily lost the most talented black basketball players to white institutions after desegregation, although the 1990-1999 decade was an outlier in the percentage of HBCUs draft choices. Further evidence can be seen by examining the decade of the 1970's, the period that produced the largest number of HBCU draftees and the era when desegregation of college athletics began in earnest in the South. Texas Western beat the all-white Kentucky squad in the spring of 1967. If a white coach at a segregated school reacted immediately which was unlikely given the intense internal and external politics surrounding integration, black recruits could not arrive in time to graduate in four years and be drafted until 1971. It was not very probable that the new wave of black athletes were recruited away from HBCUs so quickly. Table 2 illustrates these draft trends in the Seventies. From 1970 to 1974, HBCUs were still a major source for black basketball players, but in the next five years, that number was halved and the effects of increased desegregation can be seen (National Basketball Association, 2008). 
Table 2. HBCU athletes in the Period of Desegregation Transition (1970-1979)

\begin{tabular}{cccc}
\hline Year & $\begin{array}{c}\text { Total college players } \\
\text { drafted into the NBA }\end{array}$ & $\begin{array}{c}\text { Players drafted from } \\
\text { HBCUs }\end{array}$ & $\begin{array}{c}\text { Percent of players from } \\
\text { HBCUs }\end{array}$ \\
\hline $\mathbf{1 9 7 0 - 1 9 7 4}$ & 1,030 & 44 & $4.27 \%$ \\
$\mathbf{1 9 7 5 - 1 9 7 9}$ & 921 & 20 & $2.17 \%$
\end{tabular}

Source: BasketballReference.Com, NBA Draft History.com

While the number of overall HBCU draft picks is significant, it does not reflect the caliber of players involved. The predicted level of play of a draftee is determined by his draft round. Players drafted in the first or second round are considered likely to make the team and therefore are the subject of hours of film study, interviews and physical tests. Table 3 shows the decline in the number of first and second round NBA drafts picks from HBCUs as desegregation accelerated. This trend holds despite the fact that the number of teams in the NBA increased from 11 in 1947 to 30 in 2011.

Table 3. HBCU athletes in NBA Draft Round 1 \& Round 2 (1947-2011)

\begin{tabular}{ccccc}
\hline Year & $\begin{array}{c}\text { Round 1 College } \\
\text { Players drafted } \\
\text { from HBCUs }\end{array}$ & $\begin{array}{c}\text { Round 2 College } \\
\text { Players drafted } \\
\text { from HBCUs }\end{array}$ & $\begin{array}{c}\text { Total HBCU } \\
\text { Draftees Round 1 } \\
\boldsymbol{\&} \mathbf{2}\end{array}$ & $\begin{array}{c}\text { Percentage } \\
\text { HBCU Draftees } \\
\text { Round 1 \& 2 }\end{array}$ \\
\hline $\mathbf{1 9 4 7 - 1 9 7 9}$ & 14 & 12 & 26 & .023 \\
$\mathbf{1 9 8 0 - 2 0 1 1}$ & 4 & 6 & 10 & .005 \\
\hline
\end{tabular}

Source: BasketballReference.Com, NBADraftHistory.com, nbahoopsonline.com, nbadraft.net

Looking at the first half of the NBA draft from 1947 to 1979 and comparing that to the second half of the NBA draft from 1980-2011 reveals clear changes in players drafted from HBCUs. From 1947-1979, 26 players from HBCUs were drafted in the first and second rounds of the NBA Draft. From 1980-2011, only 10 players from HBCUs were drafted into the first and second rounds (Sports Reference, 2011). The decline was greatest among first rounders. The impact of desegregation on both the overall number of draftable HBCU basketball athletes as well as and the most elite players is unmistakable.

\section{Football}

The integration of college football followed a similar trajectory to college basketball with similar consequences for HBCUs. Just as a 1966 championship game performance by black players served to drive the integration of college basketball, so too would a dominant performance in 1970 by an African American fullback usher in a new era of integrated college football. The 1970 game featured the integrated USC Trojans versus Bear Bryant's all white Alabama Crimson Tide was played in Birmingham before 72,175 screaming fans. The Trojans star was a six foot three, 230-pound African American athlete, Sam Cunningham, (Travers, 2007) who ran all over Alabama's defense for 135 yards and two touchdowns in a 42-21 Trojan victory (Yeager, 2006). In his book, One Night, Two Teams: Alabama vs. USC and the Game that Changed a Nation, Bear Bryant's assistant coach, Oat Dye, commented on Cunningham's performance.." We played eight linebackers, looking for someone who could tackle [Cunningham]...we never found one who could tackle him" (Travers, 2007, p. 356).

For Cunningham, it was just another game he wanted to win, but the contest proved to be a much greater significance than a mere gridiron victory. Reflecting back on the game as he was inducted into the College Football Hall of Fame, Cunningham remarked,

I'm sure Coach Bryant had a desire to recruit black athletes, but the powers to be that he worked for was not allowing that. That game demonstrated how much better as a team they could be if they were allowed to integrate. Over the course of time, I realized how historic it was and what we had done that evening (Rosenstein, 2011, p.1).

Gene Stallings, the Texas A\&M head coach in 1970, said, "When I went to Texas A\&M (in the late '60s), we had no black players at that time....Sam Cunningham, the way he played against Alabama, he made a difference in the Southeastern Conference" (Stallings, 2011, p 1). After the 1970 game, former Bryant player and Kentucky coach Jerry Claiborne hyperbolically noted, "Sam Cunningham did more for integration in sixty minutes than Martin Luther King did in twenty years" (Briley, 2006, p. 139). Bryant recruited two black players the next year and just two 
years later in 1973, with a third of his starter's black, won a share of the national championship. Only ten years earlier, Governor George Wallace in his Alabama inaugural address had vowed "segregation now, segregation tomorrow, segregation forever" (Wallace, 1963, p. 2).

So the stage was set for southern white universities to begin seeking exceptional black athletes to play football, while simultaneously diluting the talent available to HBCUs. That trend impacted future NFL drafts as Table 5 shows.

Table 4. HBCU athletes drafted into the NFL (1936-2011)

\begin{tabular}{cccc}
\hline Year & $\begin{array}{c}\text { All players drafted } \\
\text { into the NFL }\end{array}$ & $\begin{array}{c}\text { Players drafted from } \\
\text { HBCUs }\end{array}$ & $\begin{array}{c}\text { Percent of players } \\
\text { from HBCUs }\end{array}$ \\
\hline $\mathbf{1 9 3 6 - 1 9 4 9}$ & 2,836 & 1 & $0.04 \%$ \\
$\mathbf{1 9 5 0 - 1 9 5 9}$ & 3,632 & 43 & $1.20 \%$ \\
$\mathbf{1 9 6 0 - 1 9 6 9}$ & 3,294 & 289 & $8.80 \%$ \\
$\mathbf{1 9 7 0 - 1 9 7 9}$ & 4,138 & 425 & $10.30 \%$ \\
$\mathbf{1 9 8 0 - 1 9 8 9}$ & 3,342 & 182 & $5.45 \%$ \\
$\mathbf{1 9 9 0 - 1 9 9 9}$ & 2,684 & 139 & $5.20 \%$ \\
$\mathbf{2 0 0 0 - 2 0 1 1}$ & 2,806 & 58 & $2.10 \%$ \\
Totals & 22,732 & 1,137 & $5.00 \%$ \\
\hline
\end{tabular}

Source: Chris Malumphy, "Draft History by College.” Drafthistory Publishing. 2010 and NFL.com.

Professional football was slow in general to draft African-Americans. The Washington Redskins remained segregated during the Fifties and did not draft a black player until they picked Bobby Mitchell in 1962 (African American Registry, n.d.). From the start of the NFL Draft in 1936 to 2011, 22,732 players were drafted. Of those, 1,137 players were drafted from HBCUs (National Football League, 2011) or 5\% of that draft period. It is evident, however, that HBCUs reached their peak numbers of athletes drafted in the early 1970s and then began a steady decline to the present day.

In the first 23 years (1936-1959) of the NFL draft when many white professional teams and white fans were wary of drafting black players, only 44 of the 6,468 athletes selected were from HBCUs (National Football League, 2011). In the next two decades, (1960 to 1979), HBCUs provided 734 draftees. As integration in college athletics, at least, became more prevalent, in the two decades between 1980 and 1999, only 321 came from HBCUs. In 1977, the NFL reduced the number of rounds from 17 to 12 and in 1994 to 7 which explains the decrease in the overall total of players drafted, even though the number of teams has expanded. So again the percentages of HBCU draftees are more significant than the raw number.

Again the transitional decade was the Seventies as Table 6 shows. Once Bear Bryant started to recruit black players to Alabama in 1971, other southern coaches had to follow suit. As the integration movement was just getting started, 274 players from HBCUs or $12.8 \%$ were drafted by the NFL in 1970-1974, but in the classes after Bryant and his coaching competitors changed their recruiting targets, the HBCU number fell to 151 in 1975-1979 or 7.8\%. From 1980-84 that number continued to decrease to 106 or 6.3\%. From 1985-1989 and then again in 1990-1994 that number fell even further to only 86 or $4.8 \%$ in each period. In the more modern era from 1995-1999 HBCU athletes were drafted 59 times or $4.8 \%$; then 32 times from $2000-2004$ or $2.5 \%$ and 22 times from $2005-2009$ or $2 \%$.

Table 5. HBCU athletes in the Period of Desegregation Transition (1970-1979)

\begin{tabular}{cccc}
\hline Year & All NFL draftes & HBCU Players drafted & $\begin{array}{c}\text { Percent of players } \\
\text { from HBCUs }\end{array}$ \\
\hline $\mathbf{1 9 7 0 - 1 9 7 4}$ & 2,210 & 274 & $12.40 \%$ \\
$\mathbf{1 9 7 5 - 1 9 7 9}$ & 1,928 & 151 & $7.80 \%$ \\
\hline
\end{tabular}

Source: Chris Malumphy, "Draft History by College.” Drafthistory Publishing. 2010 and NFL.com.

The impact of integration also can be seen by examining individual institutions. The University of Maryland Eastern Shore, located in the village of Princess Anne, had 21 players drafted by the NFL. Only one came after 1976, however, and its football program was dropped in 1990. Alcorn State, a small rural Mississippi HBCU produced an amazing 54 NFL draft picks over the years from players over looked by the University of Mississippi, Mississippi State and Southern Mississippi during their adherence to segregation. Alcorn produced 9 NFL draft choices from 
1960-1969, 28 from 1970-1979, and 8 from 1980-1989, 8 from 1990-1999 and 0 from 2000-2009

Overall from a peak of 10.3 percent of the draft in 1970-1979, HBCUs only comprised $2 \%$ of players drafted into the NFL from 2000-2011. As was also true for college basketball, integration not only reduced the raw numbers of HBCU football draft choices, but it diminished how those athletes were evaluated. Table 6 displays First and Second round draft choices over the years.

Table 6. HBCU athletes in NFL Draft Round 1 \& Round 2 (1947-2011)

\begin{tabular}{ccccc}
\hline Year & $\begin{array}{c}\text { Round 2 } \\
\text { Round 1 HCBU } \\
\text { Players drafted }\end{array}$ & $\begin{array}{c}\text { Total HBCU Draftes } \\
\text { HBCU Players } \\
\text { drafted }\end{array}$ & $\begin{array}{c}\text { Percentage HBCU } \\
\text { Round 1 \& 2 }\end{array}$ & $\begin{array}{c}\text { Draftees Round 1 \& } \\
\text { 2 }\end{array}$ \\
\hline $\mathbf{1 9 4 7 - 1 9 7 9}$ & 18 & 37 & 55 & .059 \\
$\mathbf{1 9 8 0 - 2 0 1 1}$ & 11 & 25 & 36 & .024 \\
\hline
\end{tabular}

Source: Chris Malumphy, "Draft History by College." Drafthistory Publishing. 2010 and NFL.com.

the time of the first HBCU player drafted into the NFL (1940 from Howard University) to 1979, 18 players were drafted in the first round from HBCUs and 37 in the second round. After 1980 - to 2011, only 11 HBCU players have been drafted in the first round and 25 in the second round. As was true for the NBA, there was a significant decline over the years in the number and percent of early round draft choices from HBCUs.

\section{Explaining the Trend}

There are several factors why the aftermath of desegregation caused such a discernable decline in elite athletes attending HBCUs. Big time athletics are increasingly expensive. Without regular television contracts, shares of major conference revenues, and occasional large private donations, participation in the highest levels of competition is not possible for HBCUs or, for that matter, most TWIs.

Lack of funding impacted HBCU's athletic programs disproportionately (O'Neil, 2008). Whether comparing HBCU conferences to TWI conferences operating in the same region or of comparably classified neighboring HBCUs and TWIs, the budgetary challenges faced by HBCU are clear. The total athletic budget for the HBCU Mid-Eastern Athletic Conference in 2010 was $\$ 105,524,230$, while the Atlantic Coast Conference, in the same geographical region, s $\$ 738,052,958$. The 2010 athletic budget for two neighboring mid- majors was $\$ 11,359,035$ for HBCU Delaware State University compared to TWI University of Delaware at \$35, 251,221 (O’Neil, 2008).

Frustrations over these discrepancies were voiced by HBCU Southwestern Athletic Conference commissioner, Duer Sharp, "For so long, it was about keeping up with the Joneses...we are not even in the Joneses league anymore...A lot of our athletes are disgruntled. They're frustrated by what they don't have, and many of them leave unhappy with the experience" (O'Neil, 2008, p. 1).

Funding disparities for HBCU's athletic programs led exceptional athletes to the TWI powers for several reasons. HBCUs are not able to construct the mammoth stadiums that characterized big time football or large indoor arenas for their basketball teams. Floyd Keith, former head football coach at Howard University, was asked about his facilities compared with the much larger nearby University of Maryland College Park facilities. "You can come here and or then go to the University of Maryland. They have practice fields, so they don't get on their game field until game day, there's definitely a difference in facilities" (O'Neil, 2008, p. 1-2).

Exceptional, high caliber athletes often do not see college as the end goal. Playing sports at the professional level is the aim. The obvious choice is to pick those schools with the facilities, trainers, and coaches to improve their skills.

Athletes also have chosen larger TWIs because they are in leagues whose games create more publicity for the athlete. In addition to larger crowds, the major conferences have negotiated network television contracts that broadcast their games nationally. For example, the Atlantic Coast Conference has a $\$ 1.86$ billion contract with ABC/ESPN over 12 years. The Big Ten has a $\$ 2.8$ billion, 25-year contract with its own Big Ten network. The Pac-12 has a \$3 billion 12year contract from ESPN and Fox (Bennett, 2011). The University of Texas recently signed a $\$ 300$ million contract with ESPN to televise all things Longhorn for the next 15 years (Marshall, 2011).

For many aspiring basketball and football players the schools seen on ESPN, ABC, and CBS, in football bowl games or the NCAA basketball tournament are not HBCUs. For example, Dino Gregory, an African American basketball player with professional ambitions, grew up in Baltimore playing AAU basketball and watching the NCAA tournament every year. Dino was offered scholarships to play basketball at many top Division I schools including the 
University of Maryland which he accepted. He later reflected: "I could have went to Morgan, Coppin or any other HBCU... I wanted to play in a big conference, be on TV, have a large fan base, and be able to be noticed on a nightly basis by scouts and people who are involved with professional basketball" (Gregory, 2011). He continued:

I never in my life dreamed of going to Morgan, you walk in the gym, it's nothing out of the ordinary but when you walk in the Comcast Center it's a dream. At these white institutions the facilities are state of the art; money is constantly being poured into the programs. You're always playing on television and when you graduate your degree is looked at with more respect compared to an HBCU... I have friends who play at HBCU's and they love it there but they always tell me they would switch places with me in a minute just because of the facilities, the TV time, more notice by scouts and the respect. (Gregory, 2011)

After graduating from the University of Maryland, Gregory became a professional basketball player in Europe and these opportunities far surpassed any he thought he would get competing for an HBCU.

To some extent, the relative decline of HBCU athletics is just a reflection of the same factors that have affected all the so-called mid-majors, white as well as black. In the modern athletics arm race, some powers spend more to put their football team on the field than on the whole athletic budget of the mid-majors. During the segregation era, however, HBCUs were shielded from the economic determinants of athletic success, since they had access to a cache of black athletes the region's white institutions would not touch.

If desegregation has caused African-American athletes to leave HBCUs in favor of larger better funded TWIs, is that a benefit or loss for the larger society? In the desegregated era, there are some benefits to individual black athletes whose high draft status may make them young millionaires. More important, the desegregation of public TWI's made them begin to serve all of the state's citizens which hard racial lines had previously prohibited. Mixed race audiences cheering for university teams of both black and white athletes all wearing Carolina blue or Alabama crimson may build bridges that decrease racial tensions in society.

\section{Broader implications}

If that integration is progress, a larger question remains. What is the future of HBCUs? What do their courageous past contributions in a segregated society suggest about their future in a desegregated era in which exposure to diversity is considered a touchstone of a good education? Does the price paid by the athletic programs of HBCUs after desegregation reflect their institutional competitiveness in other areas as well? That is a very complex question which certainly cannot be answered by looking at professional league draft choices.

TWIs do not simply seek premier black athletes; however, they also look for the talented black scholars, artists and scientists. Some of these African-Americans may respond to superior facilities at TWIs in the same way that black athletes have. Other black students, anticipating the society they will live and work in, will prefer a more multiculturally diverse campuses than HBCUs typically provide. As those persons migrate from HBCUs to TWIs, it may have the same effect as the exodus of athletes in decreasing the relative competitiveness of HBCUs.

Two economists Roland Fryer (of Harvard) and Michael Greenstone (of MIT), recently have examined the salaries over time of black students graduating from HBCUs and TWIs. They found:

In the 1970s, HBCU matriculation was associated with higher wages and an increased probability of graduation, relative to attending a [traditional college]. By the 1990s, however, there is a substantial wage penalty. Overall, there is a $20 \%$ decline in the relative wages of $\mathrm{HBCU}$ graduates in just two decades. (Riley, 2010, p. 21)

This is a controversial finding and it is fair to say there are various ways to look at the evidence, (e.g. Ashley, 2007; Constantine, 1995; Ehrenberg, 1994; Greenstone, 2007; and Mills, 2008), but more recent data suggests that TWIs may be getting better at educating black students and that any former HBCU advantage may be declining.

Comparing the average SAT scores of black students attending HBCUs and TWIs make the Fryer/Greenstone research conclusion plausible. In Maryland for example, in 1999 the institutional average verbal SAT scores of black students attending the state's six TWIs was 508, while the institutional average of black students attending the four HBCUs in the state was 442 . For math SATs, the figure was 492 for the black students at TWIs and 430 for black students at HBCUs. The four year graduation rate for black students at TWIs was $53 \%$ and for black students at HBCUs $35 \%$ (Nagai, 2000). The percentage of all first year students needing some remediation was $35 \%$ at the TWIs and $50 \%$ at the HBCUs (Maryland Higher Education Commission, 1996). It may be that black students who now prefer TWIs for athletic reasons are also being accompanied by those talented in academics.

The names of the dominant HCBU athletes such as Earl Monroe, Sam Jones, Willis Reed, Walter Payton, Jerry Rice, 
Bob Hayes, Mel Blount, and Doug Williams from the segregated 1950's-1970 era are still enshrined in the record books. Highlights from their remarkable pro careers prove their ability to overcome second class college facilities to compete with the best athletes produced anywhere.

With the end of segregation, premier black athletes became vigorously recruited into previously all white institutions, while HBCUs struggled to stay competitive. This integration represents progress at several levels. Still the important role the HBCUs once played in the life and education of many athletic African American students at a time when the struggle for freedom and equality was still in progress and the outcome not certain should be remembered. They were the glory days for black colleges when they did more with less and produced excellence beyond expectations.

In higher education, institutions rarely close, but they constantly change missions and programs as markets evolve. Responding to the end of segregation in academic areas may be harder for HBCUs than restructuring their athletic options. Adjusting to changing markets and designing athletics programs to match is not unusual. Women who attend Radcliff, Barnard and Pembroke which had very limited athletic programs are now eligible to play for Harvard, Columbia, and Brown respectively. Vassar and Goucher, on the other hand, admit men and field Division III teams for them. One time Catholic football powers, Marquette, Detroit, and San Francisco, have dropped the sport, while Georgetown and Fordham still play that game, but in Division III. Notre Dame and Boston College are the only Catholic schools still playing football at the Division I level. For HBCUs, perhaps there also needs to be adjustments in their markets and athletic programs. The advantages and disadvantages that so influenced HBCU athletics before desegregation will never return.

\section{References}

Adair, A. (1984). Desegregation: The Illusion of Black Progress. Lanham, Maryland: University Press of America. Adams v. Richardson, 356 F. Supp. 92 (D.C Court of Appeals 1973).

African American Registry. (n.d.). Black Contributions American Professional Football are many. Retrieved from African American Registry: http://www.aaregistry.org/historic_events/view/black-contributions-american-professional-football-are-many

Allen, W. (2002). A Backward Glance Forward: Past, Present and Future Perspectives on HBCUs. The Review of Higher Education, 25 (3), 241-261. http://dx.doi.org/10.1353/rhe.2002.0007

Ashley, D. (2007). Are historically Black Colleges Worth It? Diverse: Issues in Higher Education .

Bennett, B. (2011, May). From TV deal, not expansion, Big East's big issue ESPN. December 2011,: http://espn.go.com/blog/ncfnation/post/_id/41660

Briley, J. D. (2006). Career in Crisis: Paul Bear Bryant and the 1971 Season of Change. Macon, Georgia: Mercer U. Press.

Brown v. Board of Education, 347 (U.S. Supreme Court 1954).

Bullock, H. A. (1967). A History of Negro Education in the South. Cambridge: Harvard U.P. http://dx.doi.org/10.4159/harvard.9780674732865

Constantine, J. (1995). The Effect of Attending Historically Black Colleges and Universitites on Future Wages of Black Students. Industrial Labor Relations Review , 531-546. http://dx.doi.org/10.2307/2524780

Davis, K. (2003, November). The Bayou Classic: Black America's biggest football game: Grambling State and Southern continues a 30-year tradition. Ebony .

Dunne, A. (1996). Secret Basketball Game of 1944. Retrieved September 2011, from North Carolina History Project: http://www.northcarolinahistory.org/encyclopedia/450/entry/

Ehrenberg, R. G. (1994). Choices and Consequences: Contemporary Policy Issues in Education. Ithaca: ILR Press.

Ellsworth, S. (1996, March 31). Jim Crow Losses; The Secret Game. New York Times Magazine .

Entine, J. (2001). Taboo: Why Black Athletes Dominate Sports and Why We're Afraid to Talk About it. New York City: Public Affairs.

Fitzpatrick, F. (2003, November ). Texas Western's 1966 title left lasting legacy. Retrieved December 2011, from ESPN Classic: http://espn.go.com/classic/s/013101_texas_western_fitzpatrick.html

Greenstone, R. F. (2007). The Causes and Consequences of Attending Historically Black Colleges and Universities. MIT Working Paper Series .

Gregory, D. (2011, December 1). (M. Bennett, Interviewer) 
Haskin, D. (2008). Basketball-1966. El Paso, Texas: University of Texas at El Paso Press.

Henderson, C. Y. (2003). Surrmounting all Odds. Greenwich: Information Age Publishing.

Hendrickson, M. C. (1997). Public Historically Black Colleges at the Crossroads. Jurnal for a lust and Caring Education, 95-113.

History \& Legends. (2011). Champion Makers: They Proved Different Styles Still Make Winners. Retrieved December 2011, from History \& Legends: Black College Sports: http://www.ehbcsports.com/index.

Jambe, Joseph (2009) Black Student Athletes Changing Football at HBCUs. Black College wire

Johnson, G. (2011). NCAA Football attendance reaches new heights. Retrieved December 2011, from National Collegiate Athletic Association http://www.ncaa.org/wps/wcm/connect/public/NCAA/Resources/Latest+News/2011/February/NCAA+football+ attendance+reaches + new + heights

Jones, B. (2007, February 27). Progress, yes; but HBCUs paid a price for it. Retrieved December 2011, from ESPN : http://sports.espn.go.com/espn/blackhistory2007/news/story?id=2780876

Knight v. Alabama, 900 F. Sup. 2002 (, ND Alabama 1995).

Latrell, S. (2010, February 1). National Signing Day 2011: For Historically Black Colleges, It's a Reality Check. Retrieved December 2011, from Bleacher http://bleacherreport.com/articles/592370-national-signing-day-for-hbcus-it-is-a-reality-check

Leas, J. S. (1994). A Legal History of Desegregation in Higher Education. Journal of Negro Education, 63 (3).

Lederman, D. (1991). Special Admissions Treatment for Athletes Widespread at Big time-Sports Colleges. Chronicle of Higher Education, 33, A1-A31.

Link, W. (1991, February ). Southern Oral History Program Collection (\#4007). (R. Dawson, Interviewer) Chapel Hill, North Carolina: Southern Historical Collection, Wilson Library.

Malumphy, C. (2010). Draft History by College. Retrieved from Drafthistory.

Marshall, K. (2011, February). National Signing Day 2011: For Historically Black Colleges its a Reality Check. Retrieved December 2011, from Report: $\mathrm{http} / / /$ bleacherreport.com/articles/592370-national-signing-day-for-hbcus-it-is-a-reality-check

Maryland Higher Education Commission. (1996, May). A Study of Remedial Education at the Maryland Public Campuses. Retrieved December 2011, from Maryland Higher Education Act Commission: 07/retentiongradratesmemo.pdf

Mills, E. M. (2008). The Wage Earnings Impact of Historically Black Colleges and Universities. Southern Economic Journal , 173-187.

Moran, B. (2008). Race and Wealth Disparities: A Multidisciplinary Discourse. Lanham: University Press of America.

Nagai, R. L. (2000, September 27). Preferences in Maryland Higher Education. Center for Equal Opportunity.

National Basketball Association. (2008). Basketball 101: NBA Draft. Retrieved December 2011, from National Basketball Association: http:??www.nba.com/bobcats.index.html

National Basketball Association. (2011, August). Legends Profile: Earl Monroe. Retrieved December 2011, from NBA.com: http://www.nba.com/history/legends/earl-monroe/index.html

National Center for Education Statistics . (2011). Status and Trends in the Education of Racial and Ethnic Minorities . Retrieved December 2011, from Institute of Education Sciences National Center for Education Statistics: http://nces.ed.gov/pubs2010/2010015/tables/table_24_4.asp

National Football League. (2010). NFL Draft. Retrieved December 2011, from National Football League: http://www.nfl.com/draft/2012

National Football League. (2011). NFL Draft History By School. Retrieved December 2011, from National Football League:

http://www.nfl.com/draft/history/fulldraft?abbr=S\& collegeName=Southern+University\&abbrFlag=0\&type=sch ool

NBA Draft History. (2011). NBA Hoops Online. Retrieved December 2011, from nba.comhttp://www.nba.com/history/draft/index/index.html 
NBA Draft.net (2011). Nbadraft.net. Retrieved December 2011, from nbadraft.net. http://nbadraft.net/nba_draft_history/1959.html

NBA Hoops Online. (2011). NBA Hoops Online. Retrieved December 2011, from nbahoopsonline.com. http://nbahoopsonline.com/History/Leagues/NBA/drafts/index.html

Nealy, M. (2008, March 28). ESPN Documentary on the HBCU Athletes Who Desegregated College Sports Scores Big. Retrieved December 2011, from ESPN: http://diverseeducation.com/article/10906/

O'Neil, D. (2008). HBCUs Struggling to Survive. Retrieved September 2011, from ESPN : http:sports.espn.go.com/ncb/columns/story?columnist=oneil_dana\&id=3232895

Papadakis, D. Y. (2006). Turning of the tide: how one game changed the south. New York City: Hatchette Digital Inc.

Ramsey, D. (2005, February). Earl Lloyd: A Basketball Pioneer. Retrieved December 2011, from NBA.com: http://www.nba.com/sixers/community/earl_lloyd_050208.html

Riley, J. (2010, October 1). Black Colleges need a new Mission. Wall Street Journal .

Rosenstein, G. (2011, July 15). USC's Sam Cunningham Set for College Football Hall of Fame. USA Today .

Meyers Sr.,, Samuel L. (1989). Desegregation in Higher Education NAFEO Research Publications. New York City: University Press of America.

Samuels, A. L. (2004). Is Separate Unequal? Black Colleges and the Challenge to Desegregation. Lawrence, Kansas: U.P. of Kansas.

Sports Reference. (2011). NBA and ABA Players. Retrieved December 2011, from BasketballReference: http://www.basketball-reference.com/frov/colleges.cgi?college=southernu

Stallings, G. (2011, July). A Game Changer for Society. Retrieved December 2011, from SouthBendTribune: http://articles.southbendtribune.com/2011-07-17/news/29785857_1_taxi-cab-driver-alabama-gene-stallings

Starks, E. B. (2006). Historically Black Colleges and Universities . Santa Barbara, California: ABC-CLIO .

Stat Sheet. (2011). College Basketball. Retrieved December 2011, from Statsheet.com: $\mathrm{http} / /$ statsheet.com/mcb/teams/grambling-state/nba_draft

Thornley, S. (1989). Basketball's Orginial Dynasty: The History of the Lakers . Minneapolis: Nodin Press.

Travers, S. (2007). One Night, Two Teams: Alabama Vs. USC and the Game that Changed a Nation. Lanham, Maryland: Taylor Trade Publications.

United Negro College Funds Inc. U. N. (2011). Why are HBCUs Important . Retrieved December 2011 http://www.uncf.org/aboutus/hbcus/asp

U.S. Department of Education. (2011, September ). White House Initiative on Historically Black Colleges and Universities. Retrieved 2011, from U.S. Department of Education: http://www2.ed.gov/about/inits/list/whhbcu/edlite-index.html

U.S. v. Jefferson County Board of Education, 377 F.2d 836, 847 (U.S. Court of Appeals 5th Circuit 1966).

U.S. Department of Education. (2010). Desegregation and HBCUs. Retrieved December 2011, from United States Department of Education : http://www.ed.gov/news/speeches/changing-hbcu-narrative

U.S Department of Education. (2007, September). White House Initiative on HBCUs . Retrieved October 2011, from United States Department of Education: http://www.ed.gov/about/inits/list/whhbcu/edlite-index.html

United States v. Fordice, 505 U.S.717 (1992).

Wallace, G. (1963, January). The 1963 Inaugural Address of George Wallace . Retrieved December 2011, from Alabama Department of Archives History: http://www.archives.alabama.gov/govs_list/inauguralspeech.html

Watkins, W. H. (2001). The White Architects of Black Education: Ideology and Power in America, 1865-1954. New York City: Teachers College Press.

Wiggins, P. M. (2004). Sport and the Color Line. London: Psychology Press.

Wolff, A. (2007, November). Early Steps on the Road to Glory; The unlikely genesis of Texas Western's historic NCAA title. Sports Illustrated .

Yaeger, D. (2006). Turning of the tide: how one game changed the South. Hachette Digital. 